\title{
Protein nano-cages: Novel carriers for optimized targeted
}

\section{remedy [version 1; peer review: 1 approved, 1 approved with}

\section{reservations]}

\section{Negar Etehad Roudi (D), Neda Saraygord-Afshari, Maryam Hemmaty}

Department of Medical Biotechnology, Faculty of Allied Medical Sciences, Iran University of Medical Sciences, Tehran, 1449614535, Iran

V1 First published: 22 Aug 2017, 6:1541

https://doi.org/10.12688/f1000research.11909.1

Latest published: 22 Aug 2017, 6:1541

https://doi.org/10.12688/f1000research.11909.1

\section{Abstract}

Since 1980, when the idea of drug-delivery was proposed, various drug-carriers have been developed, including DNA, proteins, liposomes and several other polymer cages, consisting of many well established natural and synthetic nano-particles. All these drugcarriers can self-assemble in the body and can be manipulated for safer delivery into target tissues. By definition, nano-scale drug delivery systems encompass any structure (either cage or particle) in the form of solid colloids, which range in size from $10 \mathrm{~nm}$ to $100 \mathrm{~nm}$. Today, optimization of these nano drug-vehicles is a topic in many research centers. Researchers are trying to improve the carrier's solubility and their loading capacity and also wish to increase the halflife of drug delivery cargos in target tissues. Efforts in recent years have led to the introduction of novel protein nano-cages composed of multiple protein subunits, which self-assemble within a superfine and precise format. Science their introduction these promising structure have shown many unique characteristics, including low toxicity, biosystem compatibility, minor immunogenicity, high solubility, and a relatively easy production in large scale. Herein, we review and discuss the recently developed protein nano-carriers that are used as drug cargos for targeted delivery and/or diagnostic tools.

\section{Keywords}

protein nano-cage, targeted therapy, drug delivery, drug carrier, nanotechnology

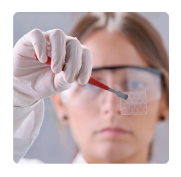

This article is included in the Nanoscience \& Nanotechnology gateway.

\author{
Open Peer Review \\ Approval Status ? \\ 2 \\ version 1

$\begin{array}{cc}\checkmark & ? \\ \text { view } & \text { view }\end{array}$ \\ 1. John G. Hardy ID, Lancaster University, \\ Lancaster, UK \\ 2. Daniela Belletti, University of Modena and \\ Reggio Emilia, Modena, Italy \\ Any reports and responses or comments on the \\ article can be found at the end of the article.
}


Corresponding author: Neda Saraygord-Afshari (neda.s.afshari@gmail.com)

Author roles: Roudi NE: Investigation, Writing - Review \& Editing; Saraygord-Afshari N: Project Administration; Hemmaty M: Investigation

Competing interests: No competing interests were disclosed.

Grant information: The author(s) declared that no grants were involved in supporting this work.

Copyright: ( 2017 Roudi NE et al. This is an open access article distributed under the terms of the Creative Commons Attribution License, which permits unrestricted use, distribution, and reproduction in any medium, provided the original work is properly cited.

How to cite this article: Roudi NE, Saraygord-Afshari N and Hemmaty M. Protein nano-cages: Novel carriers for optimized targeted remedy [version 1; peer review: 1 approved, 1 approved with reservations] F1000Research 2017, 6:1541

https://doi.org/10.12688/f1000research.11909.1

First published: 22 Aug 2017, 6:1541 https://doi.org/10.12688/f1000research.11909.1 


\section{Introduction}

Drug delivery, which refers to the technologies and approaches used for safely delivering medications into their site of action and enhancing their therapeutic effects, has gained increasing attention over the past decades. The concept of targeted drug delivery is based on the directed delivery of a certain type of drug to a certain type of cell and/or organ. During the past two decades, new approaches have been developed to control and, additionally, to increase drug delivery efficiency, leading to increased treatment competence. For example, increasing the specificity of targeted therapy, controlling the rate for drug release in the target organ and controlling the duration of drug treatment in the tissue ${ }^{1}$. The concept of controlled drug delivery has been improved gradually, over the last six decades. It began in 1980, by introducing the first sustained release formulation ${ }^{2}$. The first age of drug carrier development (1980) was focused on the development of oral and transdermal sustained release systems. These efforts have been led to the more sophisticated deciphering of drug release kinetics and the mechanisms involved. Attention during the second milestone (1980-2010) was paid to the development of controlled release systems. Introducing self-regulated drug delivery methods, long-term depot formulations and nanotechnologybased delivery cargos can be mentioned as some of the achievements of this period. Overall, different carriers for drug delivery, in micro and nano-scales have been developed and the number of drug delivery products has been increased dramatically.

Nano-scale drug delivery systems, which exhibit a greater therapeutic potential, encompass any nano-particle and/or nano-cage in the form of solid colloids that range in size from 10 to $100 \mathrm{~nm}^{1}$. Different types of materials have been designed for the application in nano-scales, including metal nano-particles (gold, silver), synthetic biodegradable polymers, and natural polymers (DNA, lipids, polysaccharides) ${ }^{3}$.

Gold nano-particles (AuNPs) are widely used as medical cargos, which provide a non-toxic vehicle for drug delivery. In these systems, AuNPs are generally designed so that the golden core meets the stability of the nano-structure, while a coating layer gives the functional properties of the surface, such as charge, hydrophobicity and specificity. An additional alluring property of AuNPs is their ability to interact with thiol functional groups, providing an effective feature for controlled release in the target tissue ${ }^{4}$.

DNA molecules can be assembled into several predesigned nano-shapes, via an organized hybridization of the sequencecomplementary domains ${ }^{5}$. These folded DNA nano-structures show a great spatial order, which can address their pronounced potential to serve as an applied and effective platform in the fields of bio-nanotechnology, as well as medicine. Of course, low toxicity and biodegradability are the characteristic features of biopolymerbased nano-particles, which leads to a considerable attention to these structures ${ }^{6}$.

Protein nano-cages are a newly emerging and promising nano-biopolymers. These structures are composed of multiple protein subunits that are self-assembled within a superfine and precise format, while showing an intricate hollow symmetrical cage-like structure at the nano-scale (1/1000 of the average width reported for a strand human hair) ${ }^{4}$. Considering the characteristic features of these new structures, herein we present and discuss these structures in detail. Different types of protein nano-cages (viral and non-viral) and the methodology of their production will be introduced, and finally the pros and cons of these new nano-cages will be discussed.

\section{Non-viral protein nano-cages}

Proteins that are used in the non-viral protein nano-structures must be capable of showing self-assembly into capsule-like shapes. These proteins naturally exist in nature. This section discusses the four most widely-used proteins: ferritin, small heat shock proteins, $\beta$-lactoglobulin and albumin.

\section{Ferritin}

This protein belongs to a family of iron storage proteins and consists of 24 subunits that are assembled to form a hollow sphere, globular protein ${ }^{6}$. In vertebrates, ferritin subunits are composed of both heavy $(\mathrm{H})$ and a light $(\mathrm{L})$ chains, which are spontaneously assembled together and surround an aqueous cavity within the internal and external diameters of about 8 and $12 \mathrm{~nm}$, respectively. In 1937, ferritin was isolated from horse spleen, but its structural features remained unidentified until 1991, when its crystal structure was resolved and determined ${ }^{7}$. The Douglas research group was the first to report the characteristics of this protein family. They showed that any changes in the ferritin external surface would not lead to a significant change on its inner surface, which is another fascinating applied feature of this protein ${ }^{8}$.

Proteins of the ferritin family are thermodynamically stable and can tolerate high temperature (up to $85^{\circ} \mathrm{C}$ ) and $\mathrm{pH}(8.5-9)$ stress. Hence, they can remain unchanged for a long time even in rigorous ionic situations. In addition, biodegradability and a non-immunogenic manner can be mentioned as the most important characteristics of these proteins, which can be applied widely in medical theranostics. Therefore, this protein family can be broadly used as mineral scaffolds and contrast-agents in MRI, and recently they have been applied for the construction of nano-protein cargoes ${ }^{8}$.

The ability of ferritin for binding to a variety of tumor markers makes it a key determinant for a variety of medical applications, especially tumor diagnosis. The $\mathrm{H}$ chain of ferritin (Hfn) consists of an arginylglycylaspartic acid (RGD) domain at its N-terminus, by the sequence of -Cys, Phe, Cys, Asp, Gly, Arg, Cys, Asp, Cys-. The RGD domain, also displayed by "C4" symbol (denoting the 4 cysteine residue present in the domain), is the main core of a ferritin protein and participates in its attachment to other structures. Additionally, the RGD domain shows some genetic variations in different species and can be adopted for different applications? ${ }^{9}$. It has been shown that Hfn-c4-RGD (Hfn integrated with RGD or C4 domain) has the ability to target THP-1, a human monocyte cell line that is derived from acute monocyte leukemia ${ }^{10}$. There are also some other reports that show that the mutant type of Hfn may have a higher performance than its wild type ${ }^{10}$.

Another well-known target for the RGD domain of Hfn is epidermal growth factor receptors (EGFR). EGFR is a famous 
biomarker that shows a high level of expression in some cancer cells. T cell-replacing factor receptor, another highly expressed receptor in cancer cells, is the other target for the RGD domain of ferritin nano-cages ${ }^{8}$.

Overall, the ability of ferritin nano-particles to co-bind to tumor biomarkers and anti-tumor agents gives them a notable therapeutic property. As an example, the co-binding of the RGD domain of Hfn to both doxorubicin (Dox) and transferrin receptor 1 facilitates the entrance of the drug to tumor cells. However, this targeted and facilitated drug delivery will lead to reduced drug dosage, as well as unwanted multidrug-resistant effect which occurs as the result of reduced peripheral exposure and decreased systemic toxicity via a more effective bio-distribution ${ }^{10,11}$.

\section{Small heat shock proteins}

Heat shock proteins (HSP) are a family of proteins that are widely expressed in living cells. They respond to stressful situations, such as heat shock, after which they were first described. The key mission of the HSP family is to maintain the correct 3D structure of proteins that are faced with undesirable denaturing conditions. Different types of HSPs exist in nature, which are named according to their molecular weight - small HSPs (sHSPs) are the category that is placed at the lower end of this classification. One of the most well-established types of sHSPs are those that are derived from Methanococcus jannaschii) MjHSP. MjHSP can form a protein nano-cage by self-assembling of 24 identical subunits into an octahedral structure ${ }^{12}$. This structure, which is characterized by $16.5 \mathrm{kDa}$ weight and 12 and $6.5 \mathrm{~nm}$ size in the outer and inner dimensions, respectively, resembles a typical ferritin nano-cage; but it has a number of large $3 \mathrm{~nm}$ pores on its surface, which makes the transport of small molecules across the cage more feasible ${ }^{13,14}$. In addition, the structure has the benefit of dramatic thermodynamic stability, similarly to ferritin nano-structures ${ }^{15}$.

MjHSP was first introduced in 2003 by Flenniken et al. ${ }^{16}$ as a multifunctional nano-scale platform. They demonstrated that this protein nano-cage has variable internal and external surfaces with a variety of reactive amine groups on their structures. The authors also engineered special selectivity for these structures by adding functional thiol groups via polymerase chain reaction-mediated site-directed mutagenesis to enhance the functional reactivity of these nanostructures. Consequently, these genetically modified structures would be able to attach to peptides, various ligand molecules and antibodies, and show versatile therapeutic applications ${ }^{16}$.

In addition, the Flenniken research group used a modified thiol group of sHSP to form a hydrogen bond with the maleimide group of Dox, which led to a successful encapsulation and efficient delivery of this chemotherapy agent. Since 24 thiol groups are located in the internal surface of sHSP, it is possible to connect 24 Dox molecules to a single sHSP nano-cage, which can then be gradually released within 24 to 25 hours of incubation in an acidic $\mathrm{pH}$ of about 4.5 to 5.5. It has been shown that $50 \%$ of these Dox molecules can be released after the first 1.5 hours at $\mathrm{pH}=5$. Effective detachment of Dox from sHSP in lysosomes has been also reported under the same conditions ${ }^{16}$.

\section{$\beta$-Lactoglobulin}

$\beta$-Lactoglobulin (BLG) is a well-known protein that is present in many mammal species. It is the major constituent of the whey obtained from sheep and cow's milk. It is a relatively small globular protein, and its regular structure comprises of an 8-stranded antiparallel $\beta$-sheet, 3 -turn structure and an $\alpha$-helix on the outer surface. Different studies have reported different ligand binding sites on this cone-like protein structure, and have proposed that a variety of hydrophobic ligands can bind successfully to BLG at $\mathrm{pH}$ values between 6 and $8 \cdot 1^{17}$. For example, retinol and fatty acids can bind to BLG's calyx binding site. This property of BLG, besides its stability in the acidic $\mathrm{pH}$, makes the structure a noteworthy choice for oral administration of drugs ${ }^{18}$. Like many other nano-structures, many studies have been conducted to improve the efficacy of nanoBLG particles to use in medical applications. For instance, solvent accessibility of ligands that bind to BLG is the main drawback of this protein as a drug carrier - this problem has been partially fixed by different approaches, such as applying a second coat, such as pectin, to protect the ligand during the delivery process ${ }^{19}$. Assembly of BLG into nano-structures has been also improved to enhance the capability of these drug delivery systems ${ }^{20,21}$.

\section{Albumin}

Albumins belong to a family of highly water-soluble, globular proteins. Ovalbumin, the main protein of egg white, bovine serum albumin, the albumin derived from cow's serum, and human serum albumin, the most abundant protein of human serum, can be mentioned as the three major types of this protein family ${ }^{22}$. The albumin family has been widely used as drug carriers, since they are easily available, have a low cost, have a feasible purification procedure, are stable in a large $\mathrm{pH}$ range (4-9), show unusual ligand-binding properties, due to their highly charge nature, and most importantly represent a preferential uptake in inflamed tissue and, surprisingly, tumors. These properties, besides their nontoxic and biodegradable nature, makes them a favorable choice for drug delivery. Assembly of albumins into well-defined nano-structures gives them additional therapeutic advantages, including high tolerance, lack of undesirable interactions with serum, high capacity for drug loading ${ }^{23}$.

\section{Virus-like nano-particles}

Virus-like particles (VLPs), are the same as viruses' capsid or protein coat, with no genetic material. These particles can induce an immune response without the risk of viral infections. Therefore, they can be applied for vaccine development. They can also be used for chemical attachment and genetic fusion. Currently, a variety of VLPs and virus like nano-particles (VLNPs) have been developed and applied.

In addition to immunogenic properties, VLPs have fascinating characteristics that make them an appropriate choice for nano-medicine, for example high variability in VLP size and shape. VLPs can be formed by association of hemo or hetero viral proteins (VPs), which are all self-assembled together and organized in a highly symmetrical, mono-disperse and stable nano or micro scale structures. Generally speaking, VLNPs can be assembled into icosahedral or helical shapes. Furthermore, although these particles are inherently well suited for nano-medicine, it is also possible to take additional 
advantage of them by manipulating the content of their functional groups via genetic engineering and changing their constituent of lysine (-NH) or cysteine (-SH) groups. This will be applied where covalent functionalization of VLNPs is the method of choice instead of being a carrier alone. Below, we introduce some of the most relevant VLNPs used as nano-drug carriers.

\section{Plant viruses}

Cowpea chlorotic mottle virus (CCMV). The use of CCMV nanoparticles as drugs and chemical carriers, besides the manipulation of their functional groups to enhance their capabilities, was first made by Douglas et al. in 2002. These authors also tried to mimic the functionality of ferritin, as a well-established iron reservoir in living organisms ${ }^{8}$. Today, the structural features of these viral nanoparticles have been well defined. We know that CCMV's protective coat consists of 180 identical protein subunits, each composed of 190 amino acids. These identical subunits are self-assembled together to form an icosahedral protein cage, which represents a $\mathrm{T}=3$ symmetry. This complex structure forms in a way so that the amine terminals of the protein chains locate in the interior side of the cavity, making it a favorable option to carry negatively charged components ${ }^{24}$. This nano-particle, which is $18 \mathrm{~nm}$ wide in its interior cavity and $28 \mathrm{~nm}$ wide as a whole (twice the diameter of ferritin), shows a very dynamic structure. For example, reassembly, disassembly and swelling of this structure due to $\mathrm{pH}$ alteration is a feature of its dynamicity. This is an important point because researchers can utilize the reversible swelling property of CCMV nano-cages, hence the process can lead to the formation of 60 openings of $2 \mathrm{~nm}$ diameters, suitable for an appropriate $\mathrm{pH}$-dependent load and release of the medical cargo ${ }^{25}$.

CCMVs can be easily obtained from the infected leaves of the virus corresponding host, Vigna unguiculata. It can also be obtained by the means of genetic engineering and the use of E. coli or yeast expression systems. When genetic engineering is the method of choice, it would be possible to make some pseudo particles with different functionality. For example, by truncating the $\mathrm{N}$-terminus of the capsid's subunits, the number of the subunits, present in the resulting particles, will be changed, along with the order of symmetry and shape, rather than icosahedral structures ${ }^{26}$.

Cowpea mosaic virus (CPMV). CPMV is another plant virus with an icosahedral structure. CPMV particles show interesting properties for drug delivery systems. For example, the recovery yield of these particles from their infected host, Vigna unguiculata, is relatively high and cost-effective. The amino acid composition and arrangement of these nano-structures is another outstanding feature. CPMV's capsid is composed of 60 protein subunits, mainly of two types, small $24 \mathrm{kDa}$ and large $41 \mathrm{kDa}$ units $^{27}$. These are self-assembled in a $28 \mathrm{~nm}$ structure, in which lysine and cysteine residues are located on the outer surface and make them a suitable carrier for many chemicals and drugs. They can also be used to improve the functionality of the structure. For example, the formation of polyethylene glycol (PEG)-maleimide ligands, which aid in reducing the particle's hydrophilicity and enhance their biocompatibility. Different ligands, such as carbohydrates, antibodies, oligonucleotides, organic dyes, biotin, peptides and proteins, react with the cysteine residues on the outer surface of the nano-cage ${ }^{28}$.
In addition to these characteristics features, CPMV particles have shown good stability against harsh chemical modifications (e.g., when conjugated with PEG), and a wide range of temperature alteration, solvent and $\mathrm{pH}$ fluctuations, which are all vital for drug delivery systems.

\section{Bacteriophages}

MS2 bacteriophage. MS2, the pathogen of the Enterobacteriaceae family, is an icosahedral bacteriophage. Its capsid is formed by self-assembly of 180 identical protein subunits into a $27 \mathrm{~nm}$ porous structure ( 32 pores of $1.8 \mathrm{~nm}$ in diameter). This protein nano-cage is stable against harsh environmental changes, such as wide variations in $\mathrm{pH}$ range (3-10) and temperature fluctuations ${ }^{29}$. The porous structure of the MS2 protein nano-cage has good stability against harsh environmental changes, making the particle a very good platform for chemical modifications and functional alterations.

The Wu research group (1995) was the first to try targeted drug delivery using the MS2 bacteriophage ${ }^{30}$. The RNA genome of this bacteriophage consists of a specific region known as translational repression RNA stem-loop (TR), which naturally has an affinity to the virus coat protein. The affinity of TR for the viral coat not only prevents the binding of ribosomes and inhibits the translation of the replicase cistron, but also plays an important role in the assembly of viral particles. The Wu research group used this affinity to encapsulate drugs into the MS2 viral cage. They successfully attached the ricin A chain (a highly fatal herbal toxin) to the TR region of the bacteriophage and showed that multiple copies of the TR-RAC conjugate can be incorporated into a single viral shell. They also made some genetic and chemical manipulations on the MS2's protein coat to add human transferrin to the surface of the shell, in order to establish receptor-mediated endocytosis in target cells ${ }^{30}$. Later, this work was followed by other researchers worldwide. For example, in 2002 a research group from the University of Leeds, manipulated the MS2 viral shell via a site-directed mutagenesis and made chimeric VLPs, which were strongly immunogenic when carrying either $\mathrm{B}$ or $\mathrm{T}$ cell epitopes. This group not only made use of a directed immunogenic response of these manipulated particles, but could also protect and effectively deliver nucleic acid-based drug cargoes ${ }^{31,32}$.

$Q \beta$ bacteriophage. $\mathrm{Q} \beta$ bacteriophage is another icosahedral virus with a diameter of $28 \mathrm{~nm}$ and a $\mathrm{T}=3$ symmetry. The protein coat of this virus consists of 180 identical proteins, of $14 \mathrm{kDa}$ molecular weight. Therefore, the structure is very similar to the MS2 bacteriophage ${ }^{33}$. Like other protein nano-particles, many studies have been conducted to make use of the $\mathrm{Q} \beta$ bacteriophage as an efficient drug vehicle. The onset of these efforts goes back to the Strable et al. (2008) who successfully incorporated unnatural amino acids into the Q $\beta$ VLPs and made some notable structural changes from the natural coat, and investigated the stability and properties of the new structure ${ }^{34}$. Many other researchers have been published since then, which report successful functionalization and/or targeting of Q $\beta$ VLPs. For instance, attachment of human transferrin to the bacteriophage protein coat ${ }^{35}$, modification of $\mathrm{Q} \beta$ coat so that viral particles can successfully target CD-22 for the treatment of certain autoimmune disorders and cancers ${ }^{36}$. The most recently published work is by Chen et al. (2016) who reduced the 
cytotoxicity of Dox by dual functionalization of Q $\beta$ VLP by PEG and this chemotherapy agent ${ }^{37}$.

\section{Human viruses}

Simian vacuolating virus 40 (SV40). SV40 is a DNA onco-virus that is found in both monkeys and humans, and belongs to the family of Polyomaviridae that all have an icosahedral structure. Viral proteins that participate in the structure of SV40 varies depending on the early or late translation of the virus genome. The main coat protein of SV40 is viral protein 1 (VP1), which is produced by early transcription of this viral genome with a Svedberg constant of 16 . Late transcription of the SV40 genome not only yields VP1, but also two other smaller (19s) viral proteins, VP2 and VP3. A SV40 virus that only consists of VP1 yields a $\mathrm{T}=7 \mathrm{~d}$ (triangulation number 7 dextro) in a $45 \mathrm{~nm}$ icosahedral structure composed of 72 pentamers assembled together ${ }^{38,39}$.

Like the other VLPs, SV40 VLPs can also be used as a drug delivery system. The variable structure of these VLPs, influenced by the types of VPs, provides a specific flexibility in design and applications. Many studies have been focused on specific targeting, as well as functionalization of SV40 VLPs. For instance, genetic modifications of the core proteins for directed targeting ${ }^{40,41}$, gene delivery and transduction of multiple cell type and so on ${ }^{42-44}$.

Murine polyomavirus. Like SV40, murine polyomavirus belongs to the family of Polyomaviridae. The protein coat of this virus is composed of an outer layer, which resembles SV40's structure, and forms via self-assembly of $360 \mathrm{VP} 1$ units, ordered in 72 pentamers and a $\mathrm{T}=7$ icosahedral structure. However, it differs from SV40 due to the presence of an additional inner layer, which is composed of both VP2 and VP3 subunits ${ }^{45}$.

In 2005 Brinkman and his colleagues surveyed the beneficial therapeutic effects with different particulate structures of murine polyomavirus VP1-coat protein. They showed that polyomaviruslike-particles (PLPs) represent a highly potent antigen-delivery system for inducing cytotoxic $\mathrm{T}$ lymphocyte responses, which can be applied for the treatment of malignant diseases via immunotherapeutic approaches ${ }^{46}$. Many other notable studies have focused on the genetic manipulation of VP1 subunits of the PLP outer layer in order to render some specific functionalities to these VLPs. For instance, Schmidt et al. added a special protein domain named WW (because of its two conserved tryptophan residues) to PLP's VP1 $\mathrm{s}^{46}$. Via this modification, PLPs gained a specific affinity for proline-rich ligands. The authors showed that this affinity leads to the efficient encapsulation of a variety of ligands to the $\mathrm{PLPs}^{47}$. Attachment of charged groups to the interior layer of the
$\mathrm{PLPs}^{48}$, and efficient encapsulation of the foreign cargoes via an anchoring technique for $\mathrm{VP} 1 \mathrm{~s}^{49}$ can also be mentioned as some other examples.

\section{General strategies to produce protein nano-cages}

There are two main strategies for providing proteins involved in a nano-cage structure. As mentioned, a simple approach is to obtain and purify viral and non-viral proteins from their natural sources. For example, MjHSP from Methanococcus jannaschii I or CCMV from Vigna unguiculata. The other approach is to produce both viral and non-viral proteins by the means of genetic engineering followed by sufficient expression in a suitable host (in most cases E. coli). The expressed proteins will be purified and undergo an assembly/disassembly process by the application of some gentle environmental changes (such as $\mathrm{pH}$ changes), in the presence of or absence of the drugs to be delivered. For the latter approach, much more consideration should be applied for constructing viral protein nano-particles due to their hazards and complexity. Using genetic engineering, the possibility for manipulation of the structure for a desired purpose can also be provided by the researcher ${ }^{50-52}$.

\section{Conclusions}

Today, nano-protein carriers, which are produced and designed via bioengineering and nanotechnology approaches, can be introduced as an effective platform for drug delivery. Since this idea has been modeled from nature, it can be applied in many medical applications, passing many of the adverse effects associated with the other common platforms.

The perfect and definite structure of nano protein-carriers - low toxicity, biodegradability, biocompatibility, low and/or directed immunogenicity, size variability, ease of functionalization, opportunity of large scale production, water solubility - are the unique characteristics of nano protein-carriers in comparison to other delivery media, such as gold nano-particles and lipid nano-particles. Hence, although nano protein-carriers are in their infancy and have not yet been tested in clinical trials, their characteristic features will lead to a vast demand for exploration of these structures and development of their biomedical applications in the near future.

\section{Competing interests}

No competing interests were disclosed.

\section{Grant information}

The author(s) declared that no grants were involved in supporting this work.
1. Safari J, Zarnegar Z: Advanced drug delivery systems: Nanotechnology of health design A review. J Saudi Chem Soc. 2014; 18(2): 85-99. Publisher Full Text

2. Park K: Controlled drug delivery systems: past forward and future back J Control Release. 2014; 190: 3-8.

PubMed Abstract | Publisher Full Text | Free Full Text
3. Chatterji A, Burns LL, Taylor SS, et al:: Cowpea mosaic virus: from the presentation of antigenic peptides to the display of active biomaterials. Intervirology. 2002; 45(4-6): 362-370. PubMed Abstract | Publisher Full Text

4. Khan AK, Rashid R, Murtaza G, et al:: Gold Nanoparticles: Synthesis and Applications in Drug Delivery. Trop J Pharm Res. 2014; 13(7): 
1169-1177

Publisher Full Text

5. Suci PA, Varpness Z, Gillitzer E, et al:: Targeting and photodynamic killing of a microbial pathogen using protein cage architectures functionalized with a photosensitizer. Langmuir. 2007; 23(24): 12280-12286.

PubMed Abstract | Publisher Full Text

6. Lohcharoenkal W, Wang L, Chen YC, et al:: Protein Nanoparticles as Drug Delivery Carriers for Cancer Therapy. Biomed Res Int. Hindawi Publishing Corporation; 2014; 2014: 180549.

PubMed Abstract | Publisher Full Text | Free Full Text

7. Uchida M, Willits DA, Muller $\mathrm{K}$, et al.: Intracellular distribution of macrophage targeting ferritin-iron oxide nanocomposite. Adv Mater. 2009; 21(4): 458-462. Publisher Full Text

8. Douglas T, Dickson DP, Betteridge S, et al:: Synthesis and Structure of an Iron(III) Sulfide-Ferritin Bioinorganic Nanocomposite. Science. 1995; 269(5220): 54-7. PubMed Abstract | Publisher Full Text

9. Toita $\mathrm{R}$, Murata $\mathrm{M}, \mathrm{Abe} \mathrm{K}$, et al:: Biological evaluation of protein nanocapsules containing doxorubicin. Int J Nanomedicine. 2013; 8(1): 1989-1999. PubMed Abstract | Publisher Full Text | Free Full Text

10. Schoonen L, van Hest JC: Functionalization of protein-based nanocages for drug delivery applications. Nanoscale. 2014; 6(13): 7124-41. PubMed Abstract | Publisher Full Tex

11. Mundra V, Li W, Mahato RI: Nanoparticle-mediated drug delivery for treating melanoma. Nanomedicine (Lond). 2015; 10(16): 2613-33. PubMed Abstract | Publisher Full Text | Free Full Text

12. Mura S, Nicolas J, Couvreur P: Stimuli-responsive nanocarriers for drug delivery. Nat Mater. 2013; 12(11): 991-1003.

PubMed Abstract | Publisher Full Text

13. Flenniken ML, Liepold LO, Crowley BE, et al.: Selective attachment and release of a chemotherapeutic agent from the interior of a protein cage architecture. Chem Commun (Camb). 2005; (4): 447-449. PubMed Abstract | Publisher Full Text

14. Uchida $\mathrm{M}$, Kosuge $\mathrm{H}$, Terashima $\mathrm{M}$, et al.: Protein cage nanoparticles bearing the LyP-1 peptide for enhanced imaging of macrophage-rich vascular lesions. ACS Nano. 2011; 5(4): 2493-2502. PubMed Abstract | Publisher Full Text | Free Full Text

15. Kim KK, Kim R, Kim SH: Crystal structure of a small heat-shock protein. Nature. 1998; 394(6693): 595-599.

PubMed Abstract | Publisher Full Tex

16. Zhen Z, Tang W, Guo C, et al:: Ferritin nanocages to encapsulate and deliver photosensitizers for efficient photodynamic therapy against cancer. ACS Nano. 2013; 7(8): 6988-96.

PubMed Abstract | Publisher Full Text | Free Full Text

17. Muresan S, van der Bent A, de Wolf FA: Interaction of beta-lactoglobulin with small hydrophobic ligands as monitored by fluorometry and equilibrium dialysis: nonlinear quenching effects related to protein--protein association. J Agric Food Chem. 2001; 49(5): 2609-18.

PubMed Abstract | Publisher Full Text

18. Panyam J, Labhasetwar V: Biodegradable nanoparticles for drug and gene delivery to cells and tissue. Adv Drug Deliv Rev. 2003; 55(3): 329-47. PubMed Abstract | Publisher Full Tex

19. Izadi Z, Divsalar A, Saboury AA, et al:: $\beta$-lactoglobulin-pectin Nanoparticle-based Oral Drug Delivery System for Potential Treatment of Colon Cancer. Chem Biol Drug Des. 2016; 88(2): 209-16

PubMed Abstract | Publisher Full Text

20. Torchilin VP: Micellar nanocarriers: pharmaceutical perspectives. Pharm Res. 2007: 24(1): 1-16.

PubMed Abstract | Publisher Full Text

21. Ghalandari B, Divsalar A, Saboury AA, et al: $\beta$-Lactoglobulin nanoparticle as chemotherapy agent carrier for oral drug delivery system. Journal of the Iranian Chemical Society. 2015; 12(4): 613-619.

Publisher Full Text

22. McAlpine AS, Sawyer L: $\beta$-lactoglobulin: a protein drug carrier? Biochem Soc Trans. 1990; 18(5): 879

PubMed Abstract | Publisher Full Text

23. Batrakova EV, Kabanov AV: Pluronic block copolymers: evolution of drug delivery concept from inert nanocarriers to biological response modifiers. J Control Release. 2008; 130(2): 98-106.

PubMed Abstract | Publisher Full Text | Free Full Text

24. Kratz F: Albumin as a drug carrier: design of prodrugs, drug conjugates and nanoparticles. J Control Release. 2008; 132(3): 171-183.

PubMed Abstract | Publisher Full Text

25. Bairagi U, Mittal P, Mishra B: Albumin: A Versatile Drug Carrier. Austin Therapeutics. 2015; 2(2).

Reference Source

26. Gillitzer $\mathrm{E}$, Willits $\mathrm{D}$, Young $\mathrm{M}$, et al: Chemical modification of a viral cage for multivalent presentation. Chem Commun (Camb). 2002; (20): 2390-2391. PubMed Abstract | Publisher Full Text

27. Gillitzer E, Suci $P$, Young M, et al.: Controlled ligand display on a symmetrical protein-cage architecture through mixed assembly. Small. 2006; 2(8-9): 962-966. PubMed Abstract | Publisher Full Text

28. Ganta S, Devalapally $\mathrm{H}$, Shahiwala A, et al:: A review of stimuli-responsive nanocarriers for drug and gene delivery. J Control Release. 2008; 126(3): 187-204. PubMed Abstract | Publisher Full Text
29. Prasuhn DE Jr, Singh P, Strable E, et al.: Plasma clearance of bacteriophage Qbeta particles as a function of surface charge. J Am Chem Soc. 2008; 130(4): $1328-1334$

PubMed Abstract | Publisher Full Text | Free Full Text

30. Kawano M, Matsui M, Handa $\mathrm{H}$ : SV40 virus-like particles as an effective delivery system and its application to a vaccine carrier. Expert Rev Vaccines. 2013; 12(2): 199-210. PubMed Abstract | Publisher Full Text

31. Wu M, Brown WL, Stockley PG: Cell-specific delivery of bacteriophageencapsidated ricin A chain. Bioconjug Chem. 1995; 6(5): 587-595. PubMed Abstract | Publisher Full Text

32. Brown WL, Mastico RA, Wu M, et al:: RNA bacteriophage capsid-mediated drug delivery and epitope presentation. Intervirology. 2002; 45(4-6): 371-80. PubMed Abstract | Publisher Full Text

33. Fu Y, Li J: A novel delivery platform based on Bacteriophage MS2 virus-like particles. Virus Res. 2016; 211: 9-16. PubMed Abstract | Publisher Full Tex

34. Golmohammadi R, Fridborg K, Bundule M, et al: The crystal structure of bacteriophage $Q$ beta at 3.5 A resolution. Structure. 1996; 4(5): 543-554. PubMed Abstract | Publisher Full Text

35. Sen Gupta S, Kuzelka J, Singh $P$, et al.: Accelerated bioorthogonal conjugation: a practical method for the ligation of diverse functional molecules to a polyvalent virus scaffold. Bioconjug Chem. 2005; 16(6): 1572-1579. PubMed Abstract | Publisher Full Text

36. Strable E, Prasuhn DE Jr, Udit AK, et al:: Unnatural amino acid incorporation into virus-like particles. Bioconjug Chem. 2008; 19(4): 866-875. PubMed Abstract | Publisher Full Text | Free Full Text

37. Rhee JK, Baksh M, Nycholat C, et al:: Glycan-targeted virus-like nanoparticles for photodynamic therapy. Biomacromolecules. 2012; 13(8): 2333-2338. PubMed Abstract | Publisher Full Text | Free Full Text

38. Chen Z, Li N, Chen L, et al.: Dual Functionalized Bacteriophage Q $\beta$ as a Photocaged Drug Carrier. Small. 2016; 12(33): 4563-71.

PubMed Abstract | Publisher Full Tex

39. Kler S, Asor R, Li C, et al:: RNA encapsidation by SV40-derived nanoparticles follows a rapid two-state mechanism. J Am Chem Soc. 2012; 134(21): 8823-8830. PubMed Abstract | Publisher Full Text | Free Full Text

40. Kawano T, Murata M, Piao JS, et al:: Systemic delivery of protein nanocages bearing CTT peptides for enhanced imaging of MMP-2 expression in metastatic tumor models. Int J Mol Sci. 2014; 16(1): 148-58. PubMed Abstract | Publisher Full Text | Free Full Text

41. Schmidt U, Günther $C$, Rudolph R, et al.: Protein and peptide delivery via engineered polyomavirus-like particles. FASEB J. 2001; 15(9): 1646-8. PubMed Abstract | Publisher Full Text

42. Schmidt $U$, Rudolph $R$, Böhm G: Binding of external ligands onto an engineered virus capsid. Protein Eng. 2001; 14(10): 769-74. PubMled Abstract | Publisher Full Text

43. Kimchi-Sarfaty C, Alexander NS, Brittain S, et al:: Transduction of multiple cell yypes using improved conditions for gene delivery and expression of SV40 pseudovirions packaged in vitro. Biotechniqes. 2004; 37(2): 270-275. PubMed Abstract

44. Sun X, Li W, Zhang X, et al.: In Vivo Targeting and Imaging of Atherosclerosis Using Multifunctional Virus-Like Particles of Simian Virus 40. Nano Lett. 2016; 16(10): 6164-6171.

PubMed Abstract | Publisher Full Text

45. Georgens C, Weyermann J, Zimmer A: Recombinant virus like particles as drug delivery system. Curr Pharm Biotechnol. 2005; 6(1): 49-55.

PubMed Abstract | Publisher Full Text

46. Ramqvist $T$, Dalianis $T$ : Lessons from immune responses and vaccines against murine polyomavirus infection and polyomavirus-induced tumours potentially useful for studies on human polyomaviruses. Anticancer Res. 2010; 30(2): 279-84. PubMed Abstract

47. Brinkman M, Walter J, Grein S, et al.: Beneficial therapeutic effects with differen particulate structures of murine polyomavirus VP1-coat protein carrying self or non-self CD8 T cell epitopes against murine melanoma. Cancer Immunol Immunother. 2005; 54(6): 611-22. PubMed Abstract | Publisher Full Text

48. Schmidt U, Rudolph R, Böhm G: Mechanism of assembly of recombinant murine polyomavirus-like particles. J Virol. 2000; 74(4): 1658-1662.

PubMed Abstract | Publisher Full Text | Free Full Text

49. Bellini M, Mazzucchelli S, Galbiati E, et al:: Protein nanocages for self-triggered nuclear delivery of DNA-targeted chemotherapeutics in Cancer Cells. J Control Release. Elsevier. 2014; 196: 184-96.

PubMed Abstract | Publisher Full Text

50. Abbing A, Blaschke UK, Grein S, et al.: Efficient intracellular delivery of a protein and a low molecular weight substance via recombinant polyomavirus-like particles. J Biol Chem. 2004; 279(26): 27410-21.

PubMed Abstract | Publisher Full Text

51. Howard Hughes Medical Institute: Large protein nanocages could improve drug design and delivery. 2016 Reference Source

52. King NP, Bale JB, Sheffler W, et al: Accurate design of co-assembling multicomponent protein nanomaterials. Nature 2014; 510(7503): 103-108. PubMed Abstract | Publisher Full Text | Free Full Text 


\section{Open Peer Review}

\section{Current Peer Review Status:}

\section{Version 1}

Reviewer Report 25 October 2017

https://doi.org/10.5256/f1000research.12872.r26311

(C) 2017 Belletti D. This is an open access peer review report distributed under the terms of the Creative Commons Attribution License, which permits unrestricted use, distribution, and reproduction in any medium, provided the original work is properly cited.

\section{Daniela Belletti}

Department of Life Sciences, University of Modena and Reggio Emilia, Modena, Italy

Review "Protein nano-cages: Novel carriers for optimized targeted Remedy" reviews recent trend in use of protein as nanometric tools for drug delivery and diagnoses.

Overall it's a well-written, quite accurate review, but needs some revision before to be indexed.

1. Abstract is not clear and contains many conceptual error or typos.

- "Since 1980, when the idea of drug-delivery was proposed, various drug-carriers have been developed, including DNA, proteins, liposomes and several other polymer cages, consisting of many well established natural and synthetic nano-particles."

This sentence resulted not clear and too confusing: DNA, protein are material for drug delivery systems; liposomes are drug delivery systems composed by lipid.

- "All these drug-carriers can self-assemble in the body and can be manipulated for safer delivery into target tissues."

This concept is wrong, drug carrier not self assemble in the body.

- The term "carrier's solubility" is not correct, It is a colloidal system in which carrier is dispersed in the medium.

- "Science their introduction" is "Since their introduction".

2. Introduction reports many general concepts regarding the drug delivery systems produced during years. This part contains some information not useful for the general content of the review. A comment/comparison between synthetic and natural self assembling drug delivery systems should be more properly.

3. Introduction of table or image could make the review more clear.

4. The condition for the assembly of protein into nanocage are completely missing. 
Is the topic of the review discussed comprehensively in the context of the current literature?

Yes

Are all factual statements correct and adequately supported by citations?

Yes

Is the review written in accessible language?

Yes

Are the conclusions drawn appropriate in the context of the current research literature? Yes

Competing Interests: No competing interests were disclosed.

I confirm that I have read this submission and believe that I have an appropriate level of expertise to confirm that it is of an acceptable scientific standard, however I have significant reservations, as outlined above.

Reviewer Report 09 October 2017

https://doi.org/10.5256/f1000research.12872.r26080

(C) 2017 Hardy J. This is an open access peer review report distributed under the terms of the Creative Commons Attribution License, which permits unrestricted use, distribution, and reproduction in any medium, provided the original work is properly cited.

John G. Hardy

Lancaster University, Lancaster, UK

The authors present an interesting overview of protein nanocage-based drug delivery systems, which gives the reader a taster of the interesting properties of this class of nanoscale drug delivery system. The review is on the whole well written, but in need of a little editing of the text (examples of the edits are listed below).

The review article would benefit greatly from the addition of figures to help to explain the topic visually to the reader. Please ensure the figures have the appropriate citation and text from the publisher (typically something like: "This image is reproduced from XXX with permission of the publisher")

Please change the title "Protein nano-cages: Novel carriers for optimized targeted remedy" to read "Protein nanocages: Novel carriers for optimized targeted remedy"

The idea of "Drug Delivery" has been around for somewhat longer than 1980, however it is likely the authors intended to include the word "controlled" prior to drug delivery to differentiate this 
from the typical burst release profiles seen with drugs delivered via injections or oral administration.

Please change all instances of "Nano-scale" to read "Nanoscale"

"Protein nano-cages are a newly emerging and promising nano-biopolymers." should read "Protein nano-cages are an emerging technology with promise for drug delivery."

Please change "and recently they have been applied for the construction of nano-protein cargoes" to read "and recently they have been applied for the construction of protein based delivery systems"

Please change "bio-distribution" to read "biodistribution"

Please change "nano-cage" to read "nanocage"

Please change "nano-particles" to read "nanoparticles"

Is the topic of the review discussed comprehensively in the context of the current literature?

Yes

Are all factual statements correct and adequately supported by citations? Yes

Is the review written in accessible language?

Yes

Are the conclusions drawn appropriate in the context of the current research literature? Yes

Competing Interests: No competing interests were disclosed.

Reviewer Expertise: Chemistry, pharmacy, biomedical engineering, chemical engineering, drug delivery, tissue engineering, neuromodulation

I confirm that I have read this submission and believe that I have an appropriate level of expertise to confirm that it is of an acceptable scientific standard. 
The benefits of publishing with F1000Research:

- Your article is published within days, with no editorial bias

- You can publish traditional articles, null/negative results, case reports, data notes and more

- The peer review process is transparent and collaborative

- Your article is indexed in PubMed after passing peer review

- Dedicated customer support at every stage

For pre-submission enquiries, contact research@f1000.com 